\title{
OS SUJEITOS SOB OS HOLOFOTES DA MÍDIA: UMA REFLEXÃO A PARTIR DE MICHEL FOUCAULT
}

\section{SUBJECTS IN THE MEDIA SPOTLIGHT: REFLECTION BASED ON MICHEL FOUCAULT}

Sílvia Mara de Melo ${ }^{125}$

\begin{abstract}
RESUMO: Este artigo tem como objetivo refletir acerca dos acontecimentos midiáticos envolvendo sujeitos em questôes polêmicas na atualidade, e para isso analisaremos três fatos ocorridos nos anos de 2012, 2014 e 2015 que se referem a duas celebridades e uma pessoa anônima, todas vítimas de crimes digitais. Propóe-se examinar enunciados de situaçôes criminosas a partir dos pressupostos teóricos da Análise do Discurso, com ênfase nas ideias de Michel Foucault. Diante de textos jornalísticos extraídos da internet, examinamos notícias que tiveram repercussăo na mídia, uma delas foi divulgada vários dias na TV e envolve diretamente o nome da atriz brasileira Carolina Dieckmann, que teve seu computador invadido por um hacker e suas fotos íntimas vazadas na rede; o ator Stênio Garcia e sua esposa tiveram suas fotos furtadas do aparelho de celular, outro fato também comentado nas redes e na TV refere-se a uma pessoa anônima igualmente vítima de um hacker.
\end{abstract}

Palavras:chave: Análise do discurso; Crimes digitais; Mídia.

ABSTRACT: This paper proposes to think about media facts involving people in controversies matters currently and we are going to analysis three facts that occurred between 2012, 2014 and 2015 involving two celebrities and an anonymous person, everybody were victims of digital crimes. We propose to examine the utterances involving criminal situations using Discourse Analysis theories, emphasizing the ideas of Michel Foucault. With newspaper articles taken from the Internet, we examine pieces of news that had great repercussion in the media. One of them was on TV news for days and involve the name of Brazilian actress Carolina Dieckmann, who had her computer hacked and her private pictures leaked on the web; the actor Stênio Garcia and his wife had their pictures stolen of the mobile phone. Another fact broadcast on the internet and on TV news involves an anonymous person who had been victim of a hacker.

Keywords: Discourse Analysis; Digital Crimes; Media.

125 Professora adjunta na Universidade Federal da Grande Dourados (UFGD), Faculdade de Comunicaçăo, Artes e Letras (FACALE).E-mail:smaramelo2012@bol.com.br 


\section{INTRODUÇÃO}

Nossa proposta, neste artigo, é refletir acerca de situaçōes polêmicas envolvendo indivíduos famosos e anônimos em crimes digitais, e para isso iremos analisar enunciados midiáticos que circularam na internet nos anos de 2012, 2014 e 2015.

Empregamos os conceitos de Discurso, de Sujeito, do Governo de si advindos de Michel Foucault, por entender que dialogam com nossa proposta de análise, suas ideias contribuem para a compreensăo do que vem ocorrendo na atualidade no espaço midiático. Organizamos nosso trabalho da seguinte forma: na primeira seçăo, denominada "Michel Foucault e sua importância para a análise do discurso", procuramos mostrar a relevância que tal autor teve para os estudos em análise do discurso, propomos dialogar com conceitos de sua obra A hermenêutica do sujeito; na segunda seçâo, "o cuidado de si em Foucault e sua relaçấo com os acontecimentos midiáticos", trazemos à tona os acontecimentos envolvendo crimes digitais e dialogamos com Foucault no que diz respeito aos conceitos do autor sobre o cuidado de si e o governo de si; na terceira seçấo, "A lei Carolina Dieckmann: uma abordagem discursiva", refletimos acerca de questóes jurídicas envolvendo crimes digitais; por último, em "O invasor e a internauta: o desgoverno de si", mostramos um crime envolvendo um hacker que ameaçava suas vítimas depois de furtar suas contas na internet.

\section{MICHEL FOUCAULT E SUA IMPORTÂNCIA PARA A ANÁLISE DO DISCURSO}

Muitas das reflexóes de Michel Foucault se deram durante suas aulas no College de France, na França, em Paris, no século XX. Sua obra "A hermenêutica do Sujeito", (2006), nos traz, por exemplo, um agregado de reflexōes acerca do cuidado de si. É com base nos estudos de textos gregos e romanos que Foucault nos apresenta uma discussăo de temas tâo contemporâneos. Ao examinarmos acontecimentos midiáticos na atualidade a partir dos conceitos foucaultianos, podemos corroborar a tese de que ele foi um filósofo de nosso tempo e suas reflexôes podem ser relevantes em diversos campos do conhecimento.

As noçōes de Sujeito trazidas à baila por Foucault em muito contribuíram para os estudos do discurso; por essa razăo, as noçôes de subjetividade serăo tomadas aqui a fim de refletirmos acerca do sujeito envolvido em situaçóes polêmicas. Apesar de já ser considerado consenso que Michel Foucault năo tenha tido a intençăo de se tornar um analista do discurso, nunca é demais relembrar que suas reflexôes săo relevantes para esse aporte teórico-metodológico. Refletiremos sobre as matérias jornalísticas pelo viés de Foucault, tomando como obras de referência principalmente $A$ hermenêutica do sujeito (2006) e A ordem do discurso (1996). Focamos situaçóes envolvendo tanto pessoas midiáticas, quanto anônima, cujas histórias foram expostas na web. 


\section{O CUIDADO DE SI EM FOUCAULT E SUA RELAÇÃO COM OS ACONTECIMENTOS MIDIÁTICOS}

Michel Foucault (2006) aborda na obra A hermenêutica do sujeito o conceito o cuidado de si. Ao voltar-se para os estudos da Grécia, o filósofo diz que o princípio "é preciso ocupar-se consigo mesmo" era uma antiga sentença da cultura grega. Segundo ele, ocupar-se de si mesmo, delegar a outros as tarefas cotidianas para voltar-se a si é um privilégio político, econômico, social e um estilo de vida na Grécia antiga. Em suas palavras: "[...] o que está em jogo no diálogo é, pois: qual o eu de que devo ocupar-me a fim de poder, como convém ocupar-me com os outros a quem devo governar" (FOUCAULT, 2006, p. 51).

As reflexôes de Foucault vâo mostrando que o cuidado de si vai se modificando no decorrer da história. Havia a preocupaçấo no cuidado de si na cultura grega no intuito de cuidar da cidade. Era preciso primeiro cuidar de si para em seguida pensar em governar. Sua reflexâo mostra que o cuidado de si estende-se para qualquer situaçâo, para qualquer cidadăo. Ao mencionar a prática de si: a correçăo dos erros, das deformaçôes, Foucault trata do cuidado que se deve ter com a alma, náo o cuidado para tornar-se governante, mas para suportar os revezes e os problemas que a vida nos impóe.

Essas teses do filósofo nos fazem refletir acerca de como muitas pessoas têm empregado a mídia na atualidade para invadir a privacidade dos indivíduos e como a maneira de as vítimas lidarem com as tecnologias tem trazido desconforto e, ao mesmo tempo, problemas. É muito comum celebridades e também pessoas anônimas terem suas imagens afetadas pela mídia quando năo tomam o governo de si e acabam "caindo" em armadilhas criadas por pessoas mal-intencionadas. Dizemos isso com base em fatos recentes em que celebridades e também anônimos deixam-se fotografar nus por namorados ou por si mesmos e, muitas vezes, têm seus arquivos haqueados ou utilizados como forma de vingança por pessoas e mídias que querem de algum modo denegrir e até mesmo chantagear o outro a fim de se obter alguma vantagem.

Na contemporaneidade, os aparelhos celulares têm sido utilizados para várias funçôes e estâo à máo de qualquer usuário a qualquer tempo; por essa razâo, qualquer um, em qualquer momento ou situaçăo, pode ser filmado, fotografado, "vigiado" por uma câmera de aparelho celular ou até mesmo por outro tipo de tecnologia.

Nesse sentido, tomar o governo de si ou ter o cuidado de si tem sido cada dia mais difícil, se considerarmos a nossa cultura cibernética. Tomemos, por exemplo, o caso Carolina Dieckmann, que, em 2012, teve seu computador invadido por hackers e suas fotos íntimas foram parar na internet. A atriz, que năo se conformou com a invasăo de privacidade, foi até as últimas consequências para punir os culpados pelo ocorrido. Com esse acontecimento, surgiu a lei n. ${ }^{\circ}$ 12.737/2012, apelidada de lei "Carolina Dieckmann". Tal lei altera o código penal para tipificar como infraçóes uma série de condutas no ambiente digital, principalmente as de invasáo de computadores, além de estabelecer puniçôes específicas, algo inédito até entâo. Outro acontecimento nesta ordem ocorreu mais recentemente, em 2015, com o ator brasileiro Stênio Garcia e sua esposa, que tiveram suas fotos íntimas furtadas de um aparelho celular. 
Na atualidade, ter o governo de si é algo complexo, já que a tecnologia que nos traz tantas facilidades pode também promover desconforto e problemas para o internauta. E o sujeito que năo quer ter sua imagem abalada por qualquer oportunista, precisa estar ainda mais atento e preocupado com o que pode lhe ocorrer. Como ter o controle de suas vidas está cada dia mais complicado, o aparelho judiciário interfere, criando leis que punam os culpados pela invasăo de privacidade. A puniçáo por crimes digitais é uma forma que o Estado encontrou de intimidar aqueles, que, por alguma razăo, tentem abalar ou desestruturar a vida de outrem. $\mathrm{O}$ aparelho jurídico entra em açâo no sentido de promover o governo de si, considerando que o sujeito usuário das novas tecnologias năo consegue fazer isso sozinho.

Outro conceito que emprestamos de A hermenêutica do sujeito é o de cultura. Nas palavras de Foucault (2006):

[...] se chamamos cultura a uma organizaçăo hierárquica de valores, acessível a todos, mas também ocasiáo de um mecanismo de seleçăo e de exclusáo; se chamarmos cultura ao fato de que esta organizaçăo hierárquica de valores solicita do indivíduo condutas regradas, dispendiosas, sacrificiais, que polarizam toda a vida; e enfim que esta organizaçăo do campo de valores e o acesso a estes valores só se possam fazer através de técnicas regradas, refletidas a de um conjunto de elementos que constituam um saber, entâo, nesta medida, podemos dizer que na época helenística e romana houve verdadeiramente uma cultura de si. (FOUCAULT, 2006, p. 221)

Segundo Foucault, é praticamente impossível falar da história da subjetividade, da relaçăo entre o sujeito e a verdade, sem inscrevê-lo no quadro da cultura de si. Para ele,

[...] se năo retomarmos a história das relaçôes entre sujeito e verdade do ponto de vista do que chamo, de modo geral, as técnicas, as tecnologias, as práticas que as compuseram e regraram, compreenderemos mal o que se passa com as ciências humanas. (FOUCAULT, 2006, p. 232).

Ele reitera o tema o cuidado de si de que o sujeito deve desviar o olhar dos outros, do cuidado com os outros e ocupar-se apenas consigo. Para Foucault (2006, p. 269)

[...] é isto o que devemos fazer conosco: olhar o que se passa náo na casa alheia, mas antes em nossa própria casa. Temos entăo a impressăo- primeira impressăo, ao menos, que se trata de substituir o conhecimento dos outros ou a malévola curiosidade em relaçăo aos outros, por um exame sério de nós mesmos.

Em tempos de tecnologia midiática cada dia mais avançada, esse curioso olhar para os outros tem se tornado muito comum, pois além dos celulares com câmeras, máquinas fotográficas, o Facebook tem se tornado também uma ferramenta utilizada pelas pessoas, de modo geral, para se mostrarem e serem vistas. No Facebook, e mais atualmente no Whats"App, o indivíduo que posta fotos dos lugares por onde viaja em férias, de algum modo, tem necessidade de mostrar para o outro que está feliz, viajando etc., e isso provoca um sentimento no outro, que pode ser de inveja, de felicidade compartilhada ou de hostilidade e indiferença. Hoje, muitos empregam o Instagram para publicar imagens do que estâo comendo, do que estăo fazendo em um dado momento. Expóem-se na rede a todos aqueles que estăo cadastrados como amigos, familiares, seguidores e făs. Professores empregam tais ferramentas para divulgar seus trabalhos, mostrando fotos de alunos, de congressos, de eventos etc. Ao nosso olhar, o querer sair do anonimato tem sido cada vez mais uma necessidade do homem, o tornar-se uma 
"celebridade", ao menos naquele pequeno nicho em que compartilha fotos e mensagens, deixou de ser mérito de artistas famosos. E, em muitos casos, essas apariçóes têm causado danos para algumas pessoas, que empregam os recursos tecnológicos sem contar que podem cair em alguma "armadilha".

Para Foucault (2006, p. 303), o cuidado de si nâo é algo que está relacionado apenas a uma fase da vida, é uma regra coextensiva à vida. "E o ser inteiro do sujeito que, ao longo de toda a sua existência deve cuidar de si". Ao dizer que o sujeito deve ir em direçâo a alguma coisa que é ele próprio, emprega a metáfora da navegaçâo, afirmando que o sujeito deve se dirigir ao porto inicial- ao seu lugar de origem, a sua pátria. Em suas palavras "A trajetória em direçâo a si terá sempre alguma coisa de odisséico" (FOUCAULT, 2006, p. 303). A trajetória é repleta de percalços, de riscos, imprevistos, e nada é garantia de segurança; ao contrário, ao se sair do lugar de origem, ao seguir seu itinerário, pode ocorrer que algo extravie o indivíduo.

Foucault (2006) entende que o sábio deve manter um conjunto de práticas para se tornar forte ao longo de sua existência. Ele cita Marco Aurélio "a arte de viver parecese mais com a luta do que com a dança, na medida em que se deve sempre manterse alerta e ereto contra os golpes imprevistos que caem sobre nós". (AURÉLIO apud FOUCAULT, 2006, p. 388-389).

As notícias que iremos examinar tratam de pessoas que sofreram golpes de internautas e tiveram suas vidas expostas e suas privacidades invadidas, ou seja, tais sujeitos náo tiveram um conjunto de práticas que as poupasse dos percalços que a vida lhes impôs.

\section{A LEI CAROLINA DIECKMANN: UMA ABORDAGEM DISCURSIVA}

A lei n. ${ }^{\circ} 12.737$, de 30 de novembro de 2012, vem ao encontro da necessidade de a sociedade punir crimes de informática e o discurso institucionalizado do aparelho jurídico torna crime ação do indivíduo que emprega os recursos tecnológicos para difamar, chantagear pessoas de modo geral.

Essa lei surge tendo em vista essas novas condiçōes de produçâo, já que, do mesmo modo que a internet promove uma nova maneira de os homens se relacionarem, ela é um recurso empregado tanto para atitudes consideradas lícitas quanto ilícitas. Considerando essa nova conjuntura, a presidente da república Dilma Rousseff sancionou tal lei para coibir atitudes invasivas de hackers, na atualidade, que vêm promovendo dissabores na vida de muitos internautas que săo tidos como vítimas desses sujeitos.

De acordo com a lei, há uma pena de três meses a um ano de reclusăo e ainda multa para aqueles que "invadem dispositivo informático alheio, que realizam obtençâo de comunicaçóes eletrônicas privadas, informaçōes sigilosas". Transcrevemos a seguir um trecho da lei:

Excerto da lei n. ${ }^{\circ}$ 12.737, de 30 de novembro de 2012:

[...] Invadir dispositivo informático alheio, conectado ou nâo à rede de computadores, mediante violaçâo indevida de mecanismo de segurança e com o fim de obter, adulterar ou destruir dados ou informaçōes sem autorizaçāo expressa ou tácita do titular do dispositivo ou instalar vulnerabilidades para obter vantagens ilícitas: 
Penas-detençăo, de 3 (três) meses a 1 (um) ano, e multa.

[...] Se da invasâo resultar a obtençâo de conteúdo de comunicaçôes eletrônicas privadas, segredos comerciais ou industriais, informaçóes sigilosas, assim definidas em lei, ou o controle remoto năo autorizado do dispositivo invadido: Penareclusâo de 6 meses a dois anos, e multa, se a conduta nâo constitui crime mais grave. $^{126}$

O que se deu com a atriz Carolina Dieckmann foi "invasăo de conteúdo sigiloso e divulgaçáo", tal como citado na lei. Neste caso e em muitos outros que têm ocorrido na atualidade, o aparelho jurídico acompanha as inovaçóes a fim de coibir os novos formatos de criminalidade.

A reclusăo em cadeias ou presídios e o pagamento de multas săo os meios que o jurídico encontrou de coibir as atitudes ilícitas. No caso específico de Carolina Dieckmann, a repercussăo na mídia ocorreu porque o nu é visto como tabu. As fotos que mostram a atriz nua só causaram tantos comentários porque em nossa cultura o sexo e o nu sâo questôes reprimidas e nâo fazem parte de nosso repertório cultural lidar com essas questóes de modo natural. Segundo Foucault (1996, p. 9):

[...] sabe-se bem que năo se tem o direito de dizer tudo, que năo se pode falar de tudo em qualquer circunstância, que qualquer um, enfim, náo pode falar de qualquer coisa. Tabu do objeto, ritual da circunstância, direito privilegiado ou exclusivo do sujeito que fala.

Mobilizamos a fala de Foucault sobre o dizer e a relacionamos às fotos nuas da atriz vazadas na internet por considerarmos que tanto o enunciado quanto as imagens trazem em seu bojo um ritual que exige ser cumprido. Falar de sexo tal como divulgar imagens de pessoas nuas săo restritas em muitas circunstâncias.

Para Foucault (1996), a sexualidade e a política constituem-se de "lugares negros" em que a "grade é mais cerrada". Com essa metáfora podemos depreender que o sexo é uma regiăo mantida ainda sob sigilo, fechada a sete chaves e que "deveria" permanecer entre quatro paredes. Esse modo de lidar com a sexualidade está relacionado à cultura de um povo.

Consideramos que há várias definiçōes de cultura no domínio dos estudos de linguagem, porém empregaremos apenas a noçăo de cultura proposta pelo filósofo Michel Foucault (2006, p. 220), para quem "cultura é uma organizaçâo hierárquica de valores [...]" a cultura, em suas palavras, "solicita do indivíduo condutas regradas, dispendiosas, sacrificiais, que polarizam toda a vida". Este conceito dialoga com os valores da atriz Carolina Dieckmann, que concedeu uma entrevista à Rede Globo e relatou detalhes do ocorrido. Tal entrevista fora divulgada no site <gl.globo.com.> Vejamos:

Carolina Dieckmann fala pela primeira vez sobre fotos e diz que espera "justiça"

Atriz deu entrevista a Patricia Poeta no Jornal Nacional desta segunda (14). Trinta e seis fotos pessoais dela foram publicadas na internet.

A atriz Carolina Dieckmann falou pela primeira vez, no Jornal Nacional da noite

126 Disponível em: 〈http://www.planalto.gov.br/ccivil_03/_ato2011-014/2012/lei/112737.htm>. Acesso em: 30 set. 2015. 
desta segunda-feira (14), sobre o roubo de 36 fotos íntimas, que foram publicadas na internet. "Acho que agora vou poder voltar a viver, porque minha vida estava em suspenso", disse, sobre o alívio que sentiu pela polícia ter encontrado suspeitos.

Em entrevista a Patrícia Poeta, ela disse que "nunca" cogitou ceder à extorsāo-a atriz afirma ter recebido um pedido de R\$ 10 mil para evitar a publicaçâo das imagens.

Emocionada, Carolina Dieckmann afirmou que sua "maior angústia" era de que o filho de 13 anos visse as fotos sem que ela estivesse presente para explicar. Contou que estava em Sáo Paulo quando foi avisada por seu empresário de que as fotos tinham vazado. Assim que soube, ligou para casa pedindo que a internet fosse desconectada até que ela pudesse conversar com Davi, seu filho mais velho. "Minha preocupaçâo era só falar para desligar a internet, porque nâo queria que ele tivesse acesso àquilo". Em seguida, a atriz diz ter ficado "muito nervosa" por estar longe da família nesse momento, e foi para a casa de uma amiga, que deu um calmante a ela.

Carolina Dieckmann disse que a decisāo de nunca ter posado nua sempre foi, em parte, pelo fato de ter um filho que hoje é adolescente. "A coisa de [năo] me expor nua tem muito a ver com eu ter um filho de 13 anos, eu sempre coloquei isso abertamente". Diante do vazamento de suas fotos, se perguntou: "Pensei: o que é pior ? Ter uma máe nua ou uma mâe que cede a uma chantagem?".

"Eu acho que ele está orgulhoso de mim", declarou, sobre a reaçâo do filho após ela ter contado a ele sobre o roubo e a exposiçâo das fotos. "Ele foi muito maduro". A atriz também falou da reaçáo e do apoio do marido, Tiago Worcman. "Eu me lembro que estava chorando muito no carro [...], eele "meu amor, calma. Ninguém morreu, năo temninguém com câncerterminal. Vocêélinda, asfotoseram para mim, tátudocerto". "O mais louco, Patrícia, é que eu não fiz nada de errado", declarou. "É uma sensaçâo de faca no peito".

Perguntada sobre o que espera agora, respondeu: "Justiça. Eu quero o que for justo".127

Pela entrevista nota-se o quanto a nossa cultura de tornar o nu como algo restrito desequilibrou, ainda que momentaneamente, a vida da atriz e fez com que perdesse o controle de si, o governo de si; quando ela diz que sua vida estava em suspenso, é porque o ocorrido promoveu um grande transtorno em seu cotidiano. Ao mesmo tempo é paradoxal este tabu em torno do nu em nossa sociedade, porque há várias revistas em que celebridades posam nuas e há uma relaçâo comercial da exposiçâo do corpo em revistas, sites etc. Assim, podemos depreender que nâo é apenas o nu que provoca polêmica, mas como ele ocorre.

O efeito de espetáculo em torno do nu deu-se, em nosso entender, porque năo houve autorizaçăo da atriz para que suas fotos fossem comercializadas e a curiosidade do internauta em ver divulgado o nu promoveu um verdadeiro turbilhâo de acontecimentos; caso a atriz tivesse posado nua para uma dessas revistas que trazem fotos sensuais de celebridades e que comercializam o nu, a repercussăo disso talvez tivesse sido outra, menos espetaculosa. Se o sexo e o nu fossem encarados com mais naturalidade em nossa sociedade, provavelmente tais crimes nem ocorressem.

O caso Carolina Dieckmann teve grande repercussâo porque há no homem, de modo geral, segundo Foucault (2006, p. 269), "uma malévola curiosidade em relaçâo aos

127 Disponível em: <http://g1.globo.com/pop-arte/noticia/2012/05/carolina-dieckmann-fala-pela-1-vezsobre-roubo-de-fotos-intimas.html . Acesso em: 24 maio 2017. 
outros". Para ele, o sujeito deve desviar o olhar dos outros, do cuidado com os outros e ocupar-se apenas consigo. Caso, no "governo de si", todos estivessem preocupados com o governo de suas vidas, tais acontecimentos năo teriam tanta relevância.

O fato de a atriz dizer que sentia angústia porque náo queria que o filho visse as fotos antes de ela poder lhe explicar, também é uma atitude que mostra a nossa cultura de encarar o nu como algo que difama e provoca constrangimento, e tal sentimento provocado na atriz pode ser endossado também pelo fato de a mesma ser măe, já que muito provavelmente outras crianças iriam ter acesso a tais fotos e isso poderia provocar um mal-estar para o filho. Carolina Dieckmann, que é casada, disse que as fotos foram tiradas e estavam arquivadas em seu computador para serem enviadas ao marido. Tendo isso em vista, o invasor, de acordo com a nova lei, será punido, já que náo lhe foi concedido o direito de invadir o computador da atriz e tornar públicos arquivos que diziam respeito apenas à proprietária do notebook.

Em 2015 o ator Stênio Garcia também foi vítima de crime digital: Vejamos o texto publicado na web:

Aos 83 anos, Stênio Garcia aparece nu ao lado da esposa em foto vazada na web

Duas "nudes" do ator Stênio Garcia, de 83 anos, ao lado de sua esposa Marilene Saade, de 47 anos, caíram na web durante a madrugada desta quarta-feira. Nas imagens, os dois aparecem completamente nus e deixam as partes íntimas à mostra em selfies tiradas pela mulher. As informaçóes sâo da revista Quem.

Stênio confirmou a veracidade da foto e falou sobre o tema para a revista Quem. "A gente brinca mesmo como todo casal saudável e náo tenho problemas com isso. Estava com a minha mulher e náo com a mulher de outra pessoa. Que problema tem isso? Nâo tenho celular há três anos. O problema foi que a Marilene registrou. Nâo tenho vergonha da nudez. Já fiquei nu várias vezes na TV e no teatro. O problema é que agora invadiram a minha privacidade. Isso é terrível!", afirmou.

$O$ ator global disse à revista que nâo sabe como as fotos vazaram, mas confirma que sua esposa deve ir à delegacia. "Por mim eu nem iria, nâo tenho nada a esconder, ando vestido na rua, mas a minha mulher quer entrar na justiça e saber quem vazou essas fotos".

Em tom de brincadeira, Stênio disse que houve apenas um problema no episódio. "O único problema nisso tudo é que eu poderia ter ganhado dinheiro com isso, mas năo ganhei. Tanta gente posa nua para revista e ganha com isso, mas eu nâo!", explicou. Durante a madrugada, o nome do ator liderou os assuntos mais comentados no Twitter. ${ }^{128}$

128 Disponível em: <http://noticias.bol.uol.com.br/ultimas-noticias/entretenimento/2015/09/30/aos-83anos-stenio-garcia-aparece-nu-ao-lado-da-esposa-em-foto-vazada-na-web.htm>. Acesso em: 30 set. 2015. 
O nu na contemporaneidade apresenta-se em vários dispositivos que săo de livre circulaçăo. Vejamos o que Fernandes diz sobre o dispositivo:

[...] o termo dispositivo refere-se a um conjunto heterogêneo que envolve discursos, instituiçóes, organizaçōes arquitetônicas, decisōes regulamentares, leis, medidas administrativas, enunciados científicos, proposiçóes filosóficas, morais, filantrópicas; ou seja, o dito e o năo dito săo os elementos do dispositivo (FERNANDES, 2012, p. 66).

Ao dizer "năo tenho vergonha da nudez. Já fiquei nu várias vezes na TV e no teatro", o ator, ao contrário de Carolina Dieckmann, demonstra tranquilidade para lidar com a situaçăo a que foi submetido. O que o ator considera "terrível" é a invasăo de privacidade, pois do mesmo modo que ocorreu com a atriz, as fotos de nudez foram furtadas do celular da esposa do Stênio Garcia. Novamente o nu promoveu a curiosidade de muitos internautas, vejamos que o texto informa: "[...] durante a madrugada, o nome do ator liderou os assuntos mais comentados no twitter". $\mathrm{O}$ ator afirma que o único problema foi que ele nâo ganhou dinheiro com a exposiçấo, já que tanta gente posa nua e recebe por isso.

Esse posicionamento de Garcia corrobora nossa tese de que o nu, quando é comercializado, por meio de dispositivos midiáticos, náo apresenta o mesmo efeito de espetacularizaçâo nos meios de comunicaçăo, tais como sites de fofoca, jornas on-line etc. O espetáculo diante do nu ou do sexo apresenta outro efeito na mídia quando nâo é autorizado pelas partes envolvidas.

\section{O INVASOR E A INTERNAUTA: O DESGOVERNO DE SI}

Outro caso de invasâo de privacidade ocorreu em outubro de 2014 quando um brasileiro foi preso por invadir perfis nas redes sociais e obrigar a vítima a fazer sexo com ele para náo ser exposta. . Vejamos o texto que elucida tal situaçăo. A notícia fora ao ar no programa fantástico em 2014 e circulou no jornal <G1.globo.com.> Ediçâo do dia 26/10/2014:

Preso Brasileiro que Invadia Perfis de Mulheres na Web

Hacker chantageava as donas dos perfis: quem quisesse ter o perfil de volta teria que fazer sexo virtual com ele.

Um hacker brasileiro invadia perfis de mulheres na internet e chantageava as verdadeiras donas: quem quisesse ter o perfil de volta teria que fazer sexo virtual com ele.

"Você não sabe quem sou eu, e você năo sabe o que eu posso fazer", diz Cristian Antônio Pereira.

Mas a mulher que conversa com ele pela internet năo sabe disso.

Cristian: Você tem cada coisa nos teus email, hein? Já acessei e vi alguma coisa.

Cristian Pereira é um hacker. Ele invadiu o perfil de uma mulher em uma rede social e também os emails dela. E conseguia impedir que a vítima desativasse as contas.

"Ele começou a querer me ver, a querer que eu tirasse a parte de cima da blusa, a querer que eu ficasse pelada para ele", conta uma das vítimas. 
Cristian: Você năo vai me mostrar os seus peitos, para eu ver? Você năo está fazendo nada que eu estou pedindo.

"E ele começou a me ameaçar, porque no meu email tinha vídeos meu e do meu namorado, e ele me ameaçou com esses vídeos", conta a vítima.

Se a mulher nâo ficasse nua para ele, Cristian publicaria no perfil dela os vídeos intimos que encontrou nos emails.

Cristian: Quando teu filho crescer, você explique para ele isso.

Ela resistiu. E foi ameaçada de estupro.

Cristian: Ou vai acontecer pela internet ou vai acontecer pessoalmente. Você que escolhe. E nâo é a primeira vez que eu faço isso, nâo.

A mulher tinha aceitado uma solicitaçâo de amizade em nome de Fred Maya, um perfil falso criado pelo hacker Cristian Pereira.

"E ele manda um link de uma foto bonita, "olha onde estou, é da minha cidade", ele era muito galanteador. E a pessoa, como estava nessa conversa e tudo, acaba clicando", diz Wanderson Castilho, peritos em crimes cibernéticos.

Ao clicar, a pessoa recebe a informaçáo falsa de que saiu da rede social. E a partir daí o hacker passava a controlar o perfil da vítima. Quando invadia um perfil, Cristian Pereira fingia ser a dona do perfil roubado e procurava as amigas dela na internet. Aconteceu com esta outra mulher.

"Eu estava conectada na internet e uma amiga minha me chamou no bate-papo", conta uma outra vítima.

Mas era Cristian. E ele pediu para conversarem por vídeo.

"Na hora que eu liguei a câmera, nâo era ela. Era o rapaz. Quando ele ligou já falou que ele tinha me assaltado. Ele falava "eu só quero ver os seus seios e devolvo as suas contas, só isso e eu devolvo as suas contas". Eu falei para ele que eu nâo ia mostrar", lembra a vítima.

Também foi ameaçada de estupro.

"Ele fazia uma pesquisa e descobria o entorno da casa da pessoa", destaca Iolanda Garay, perita em crimes cibernéticos.

"Quando ele viu que eu nâo ia ceder, ele falou "eu sei onde você mora", falou o número da minha casa", conta a vítima.

As jovens procuraram a ajuda de peritos digitais e da polícia, que descobriu: Cristian Antonio Pereira era foragido da Justiça, condenado por um estupro na cidade de Rolândia, no Paraná.

O primeiro contato com essa vítima também tinha sido pela internet.

"Eu tinha uma rede social e uma amiga minha veio falando de uma pessoa", conta a vítima.

Não era amiga nenhuma, era Cristian de novo.

"E ela falou assim tinha uma pessoa para te apresentar, você quer conhecer?", conta a vítima de estupro.

A pessoa era o próprio Cristian, éclaro. Eles marcaram encontro em uma lanchonete. Mas o criminoso levou a vítima para um terreno baldio. 
"No outro dia minhas redes sociais estavam todas raqueadas", disse a vítima de estupro.

Cristian chegou a ser condenado por esse crime em 2012.

"Condenação essa de 13 anos e 6 meses de reclusăo, cujo mandado de prisão encontra-se expedido desde 11 de setembro de 2012", destaca Márcia Rodrigues dos Anjos, promotora de Justiça.

A polícia descobriu que ele deixou o país durante o julgamento. E identificou pelos endereços de IP, a identidade digital dos computadores, que era do interior da Inglaterra que aterrorizava as brasileiras.

A Justiça já pediu a extradiçâo de Cristian Pereira para que ele cumpra no Brasil a pena pela qual foi condenado. Na Inglaterra, o rapaz também é considerado um criminoso. Cristian está preso depois de receber três acusaçóes de violência sexual.

O delegado Renato Lima representa no Paraná a Interpol, a Organizaçáo Internacional de Polícia. "Mandamos todas as informaçóes, foi feita a comparaçâo de digitais, confirmou-se que era a mesma pessoa condenada aqui", destaca.

Uma das vítimas foi avisada da prisâo de Cristian pelo advogado dela.

"E ela me respondeu por uma mensagem de voz: "Por voz é muito melhor. Eu estou impactada. Estou emocionada. Graças a Deus, eu achei que isso náo fosse acontecer", conta Leonardo Pacheco. ${ }^{129}$

Diferentemente do caso Carolina Dieckmann e de Stênio Garcia, mas envolvendo também as mídias digitais, ocorreu no ano de 2014, em que um hacker invadia perfis das redes sociais e e-mails e chantageava suas vítimas.

É importante ressaltar que do mesmo modo que pessoas de bem empregam as redes sociais, criminosos também o fazem, e os hackers sáo exímios conhecedores de tecnologia e em muitos casos empregam tal conhecimento para cometer delitos, em contrapartida, o usuário das redes sociais e das tecnologias nem sempre é um conhecedor de tais meios, na maioria das vezes, o indivíduo emprega a tecnologia sem se preocupar com o que pode acontecer com o que é publicado.

Veja-se que Cristian Pereira invadiu năo só o perfil de uma internauta das redes sociais, mas também conseguiu acessar seus e-mails. A internauta provavelmente entendia que o e-mail era um lugar mais seguro do que as redes sociais, constatou-se nâo ser. A vítima de Cristian Pereira enviava vídeos para o namorado por e-mails, ela náo os publicava nas redes sociais, pois tais vídeos eram de caráter sigiloso e tinha como interlocutor uma pessoa próxima.

O criminoso a chantageou ameaçando publicar os vídeos na rede com o propósito de denegrir a imagem da internauta. Ele pede para vê-la nua, caso contrário, iria divulgar os vídeos. Ele usa o fato de a vítima ter um filho e a ameaça dizendo que, quando a criança crescer e vir o vídeo, ela terá que explicar para ele. Esta preocupaçăo com o filho da vítima ver o vídeo e isso ser empregado como ameaça é, até certo modo, análogo ao que ocorre com Carolina Dieckmann em relaçâo ao filho, ambas as vítimas sâo máes e se preocupam de seus filhos terem contato com o nu ou com cenas de sexo. Essa questăo

129 Disponível em: «http://g1.globo.com/fantastico/noticia/2014/10/brasileiro-foragido-da-justica-invadeperfis-de-mulheres-na-web.html>. Acesso em: out. de 2014. 
em relaçấo ao sexo na sociedade contemporânea dialoga com os dizeres de Foucault em História da Sexualidade: a vontade de saber (2010), em que o filósofo reverbera que nos últimos três séculos (considera os séculos XVII, XVIII e XIX) houve uma verdadeira "explosâo discursiva" em relaçâo ao sexo, mas houve também uma "certa polícia", ou seja, um controle das enunciaçôes. Em suas palavras,

[...] definiu-se de maneira muito mais estrita onde e quando năo era possível falar dele; em que situaçóes, entre quais locutores, e em que relaçóes sociais, estabelecemse assim regiōes, senáo de silêncio absoluto, pelo o menos de tato e discriçáo: entre pais e filhos, por exemplo, ou educadores e alunos, patróes e serviçais. (FOUCAULT, 2010, p. 24)

Notamos que ainda na sociedade contemporânea há certas restriçóes em relaçăo ao que se pode dizer e ver. Tanto isso é verdade que as vítimas ficam constrangidas com a possibilidade de seus filhos terem contato com imagens do nu ou de sexo as envolvendo. A internauta afirma existirem, em seu e-mail, vídeos dela com o namorado, provavelmente há nesses vídeos cenas íntimas de um casal.

Se concordarmos com Foucault (2006) sobre o fato de que cada um deveria tomar o governo de si ao invés de se voltar ao outro, essa ameaça nem teria ocorrido. Ao se apossar dos vídeos dos e-mails da internauta e ameaçar publicá-los nas redes sociais, o hacker provoca medo e angústia em suas vítimas porque, nessas redes, as pessoas normalmente se mostram, se expóem e o outro, o interlocutor de tais conteúdos veiculados nesses meios, volta seu olhar para a vida alheia, isso porque o nu provoca a curiosidade dos homens de modo geral.

Sabe-se que vídeos pornográficos, com cenas de sexo expondo inclusive pessoas famosas săo bem comuns em nossa sociedade, eles circulam em vídeo-locadoras, nas residências de adolescentes e adultos, entre casais, em motéis, em casas noturnas. Podemos compreender todas as formas de discursos sobre o sexo como dispositivo no sentido que Foucault atribui ao termo, já que no ocidente, nas palavras de Foucault (2010, p. 29) “[...] constituiu-se uma aparelhagem para produzir discursos sobre o sexo, cada vez mais discursos, suscetíveis de funcionar e de serem efeitos de sua própria economia".

No entanto, nas condiçóes de produçăo em que se dâo tais vídeos de pessoas anônimas ou celebridades, o efeito que provoca é geralmente o de medo, terror e angústia, ao menos foram esses sentimentos que vivenciaram as duas mâes vítimas do criminoso.

Seja por ingenuidade ou excesso de confiança dos internautas, o fato é que tiveram muitos dissabores em suas vidas, já que uma das vítimas de Cristian Pereira relata que fora até estuprada por ele. Desse modo, voltamos a mencionar Foucault (2006), para quem o "cuidado de si" năo é algo que está relacionado apenas a uma fase da vida, é uma regra coextensiva à vida. É o ser inteiro do sujeito que, ao longo de toda a sua existência deve cuidar de si.

Considerando que năo há mais como evitar as tecnologias, é preciso se precaver, tomar o governo de si, para náo cair em armadilhas e poder assim suportar os revezes que a vida nos impóe. 


\section{CONSIDERAÇÕES FINAIS}

Na primeira seçâo deste artigo, denominada "Michel Foucault e sua importância para a análise do discurso", procuramos mostrar a relevância que tal filósofo teve para os estudos do discurso, já que propusemos dialogar com conceitos de sua obra $A$ hermenêutica do sujeito. Na segunda seçâo "o cuidado de si em Foucault e sua relaçâo com os acontecimentos midiáticos", trouxemos à tona os acontecimentos contemporâneos envolvendo crimes digitais e dialogamos com Michel Foucault no que diz respeito a seus conceitos sobre o cuidado de si, o governo de si e cultura. Foi possível com esta reflexăo mostrar quâo atuais săo as ideias de Michel Foucault e o quanto podemos aprender com suas abordagens.

Na terceira seçăo, "A lei Carolina Dieckmann: uma abordagem discursiva", refletimos acerca das questóes jurídicas envolvendo os crimes digitais, mostrando que o aparelho judiciário se torna necessário no cuidado e no governo de pessoas que têm suas privacidades invadidas por criminosos. Aqui, trouxemos também os conceitos de Foucault e dialogamos com ele no que diz respeito a delitos midiáticos. Por último, em "O invasor e a internauta: o desgoverno de si," mostramos uma notícia de um crime envolvendo um hacker que ameaçava suas vítimas depois de invadir suas contas na internet, mais uma vez se fez necessário dialogar com Foucault no que se refere ao governo de si.

Este artigo, ao propor uma reflexăo de um tema tăo atual, como os crimes digitais, nos faz mostrar a importância de Michel Foucault no que diz respeito a situaçóes e fatos cotidianos do século XXI. Este filósofo, que tanto tem contribuído para os estudos no âmbito da Análise do Discurso, nos ensina a observar a sociedade na qual vivemos de modo mais crítico e reflexivo. 


\section{REFERÊNCIAS}

BRASIL. Presidência da República. Casa Civil. Subchefia para Assuntos Jurídicos. Lei n. ${ }^{\circ}$ 12.737, de 30 de novembro de 2012. Disponível em: <http://www.planalto.gov.br/ ccivil_03/_ato2011-2014/2012/lei/112737.htm>. Acesso em: 04 abr. 2014.

CAROLINA DIECKMANN fala pela primeira vez sobre fotos e diz que espera "justiça". G1 - Globo.com, 2012. Disponível em: 〈http://g1.globo.com/pop-arte/noticia/2012/05/ carolina-dieckmann-fala-pela-1-vez-sobre-roubo-de-fotos-intimas.html>. Acesso em: 30 out. 2014.

FERNANDES, C. A. Discurso e Sujeito em Michel Foucault. Săo Paulo: Intermeios, 2012.

FOUCAULT, M. A ordem do discurso. Traduçâo Laura Fraga de Almeida Sampaio. 3.ed. Sâo Paulo: Loyola, 1996.

A hermenêutica do sujeito. Traduçâo: Márcio Alves da Fonseca e Salma Tannus Muchail. 2. ed. Săo Paulo: Martins Fontes, 2006.

. História da sexualidade: a vontade de saber. Traduçăo: Maria da Costa Albuquerque e J.A.Guilhon Albuquerque. 20. ed. Rio de Janeiro: Graal, 2010.

AOS OITENTA E TRÊS ANOS, STÊNIO GARCIA APARECE... Disponível em: <http://noticias.bol.uol.com.br/ultimas-noticias/entretenimento/2015/09/30/aos-83-anos-steniogarcia-aparece-nu-ao-lado-da-esposa-em-foto-vazada-na-web.htm>. Acesso em: 30 set. 2015.

PRESO BRASILEIRO QUE INVADIA perfis de mulheres na web. G1 - Globo.com, 2014. Disponível em: <http://gl.globo.com/fantastico/noticia/2014/10/brasileiro-foragido-da-justica-invade-perfis-de-mulheres-na-web.html>. Acesso em: 30 out. 2014 